\title{
8. Print and Electronic Media
}

\author{
John Sinclair
}

\section{Introduction}

This chapter provides an overview of the contrasting structure of the media industries in Australia and Latin America, and outlines some of the technological and corporate trends associated with globalisation. In Australia, there is a small commercial market of print and electronic media for people of Latin American origin, but this has inherent limitations, the advantages endowed by a common language, on one hand, being offset by the internal diversity of national and other kinds of difference on the other. In such circumstances, government plays a benign and supportive role as both a broadcaster and an advertiser. There is also a grass-roots community sector. By contrast, the media in Latin America have developed on a mass commercial basis, and have had to continually negotiate their relative independence from governments always anxious to circumscribe media influence.

Thus, compared to Latin American countries, the media environment in Australia is quite distinctive, particularly as regards the electronic media. Ever since the days of radio, Latin American broadcasting developed for the most part on the commercial model first established in the United States; that is, where broadcasters seek to attract audiences which advertisers will pay to gain access to, either by sponsoring programs or buying time spots. Commercial broadcasting was also established in Australia, but given the nation's British colonial origins, this occurred in conjunction with public broadcasting institutions largely based on the British Broadcasting Corporation (BBC) model, with an Australian Broadcasting Corporation (ABC) responsible for fostering national culture at 'arm's length' from government.

In the more recent decades during which Latin American immigrants have been arriving in Australia, the Special Broadcasting Service (SBS) has been institutionalised by government to meet the needs of a multicultural society, with a vibrant community television and radio sector growing alongside which gives linguistic and ethnic minorities direct access to the airwaves. This chapter will first present a broad comparison of the structure of the commercial media industries in Australia and Latin America, and note some global trends. An outline and analysis of the limitations of the commercial market for print 
and electronic media for people of Latin American origin in Australia then follows, and finally, the whole range of media available to these people will be described and discussed.

\section{The commercial media industries in Australia and Latin America}

There are certain similarities to be found in comparing the commercial media industries in Australia and Latin America. A common factor is that the print and electronic media have been allowed to become concentrated in their ownership, mainly under the control of a few oligarchical families. In Australia, around two-thirds of the daily press is published by News Corporation, the publishing division of the global Murdoch-owned Twenty-first Century Fox Group. ${ }^{1}$ Although international private equity capital investment has become significant in recent years, the traditional media scenario in Australia is very much the legacy of generations of Murdochs, other major families being the Packers and the Fairfaxes. To mention the most significant Latin American cases, in Brazil the two major media groups, Globo and Abril, are run today by scions of the Marinho and Civita families respectively - the grandsons of the founders - while similarly, media development in Mexico has been driven by Televisa, with successive heads of the Azcárraga family at the helm. On both sides of the Pacific, these are companies which are accustomed to dominance over their traditional print and broadcast media markets, relatively unperturbed by domestic competitors or threatened by government regulation.

However, the simultaneous intensification of globalisation and the advent of new forms of media communication in the last two decades have challenged the complacent arrangements of the preceding 'golden age' of mass media. Beginning in the 1980s, the advent of television channels distributed over international satellite-to-cable services set the stage for a new global order. Just as international news services from $\mathrm{CNN}$ and the $\mathrm{BBC}$ then became ubiquitous in the English-speaking world, so were Latin American domestic television markets opened up to CNN en Español from the US, and TVE Internacional from Spain. Several other US-based and some European channels followed, although with the next technological stage of direct-to-home satellite services, the leading entrepreneurs in Brazil and Mexico were successful in establishing partnerships with the US-based owner, DirecTV. For their part, other major

1 David McKnight, Rupert Murdoch: An Investigation of Political Power, 2012, p. 7; Nick Tabakoff, 'Historic shift for News as it returns to publishing roots', The Australian, 5 December 2012, p. 19. 
global media corporations such as News and Time Warner have long recognised the dominance which the Globo and Televisa groups enjoy in their home markets, and have at certain stages been in joint ventures with them. ${ }^{2}$

In the era of media convergence, the internet must also be taken into account, not only for the ready access to information which it gives, and its unprecedented capacity for social networking, but also as a means of delivering the traditional media of print, radio and television. Internet television has become one of the drivers for the rapid growth in broadband take-up occurring in Latin America. The region is estimated to be home to just over ten per cent of the world's internet users. Brazil has by far the largest number, followed by Mexico, Argentina, Colombia, Venezuela and Chile. Although this is very roughly in line with the relative size of these countries' populations, the percentage of penetration varies considerably: in Argentina, 67 per cent of the population has internet access, compared to 39 per cent in Brazil and 37 per cent in Mexico. The regional average is 40 per cent. ${ }^{3}$

The internet service provision business has become wholly 'Latinised', notably through initiatives taken by formerly state-owned telecommunications entities. In spite of efforts by AOL (America On Line) and other US-based ISPs (internet service providers) to corner the Latin American market in the early days of commercial internet development, it has been the Brazilian-based UOL (Universo Online) which dominates that market, while in Mexico, it is Telmex. UOL is majority-owned by the newspaper group Folha de São Paulo. ${ }^{4}$ UOL's comprehensive portal attracts 70 per cent of Brazilian users, ${ }^{5}$ the remainder being shared between Globo's internet arm, and Vivo, a brand of Telefónica. In Mexico, the former state-owned telecommunications provider Telmex is now owned by the fabled entrepreneur Carlos Slim, whose Infinitum service dominates the market. ${ }^{6}$

Telefónica is also present in Mexico, but although it is considerably outflanked there, as in Brazil, it is a significant regional player, offering its combined ISP/portal access in 17 Latin American countries, as well as in the United States, and its home base of Spain. Once Spain's state-owned telecommunications company, Telefónica is now one of the world's largest telecommunications conglomerates, with multiple interests in Latin America, and perhaps the most striking example of the influx of Spanish investment to the region over recent decades. Notwithstanding the relatively marginal position of Telefónica's ISP companies in Brazil and Mexico, it

\footnotetext{
2 John Sinclair, Latin American Television: A Global View, 1999; News Corporation, DIRECTV Group and News Corporation Announce Reorganization and Consolidation of Satellite TV Platforms in Latin America, 2004.

3 Internet World Stats, 'Latin American Internet Usage Statistics 2011'.

4 Business News Americas, 'Folha merges with UOL to form Folha-UOL'.

5 Sobre UOL, 'UOL, the best internet content'.

6 Paul Budde Communications Pty Ltd, 'Latin American Broadband and Internet Market'.
} 
is prominent in the next largest markets. In Argentina, where it is now branded as Speedy, it shares the market behind Telecom Argentina's Arnet, and Fibertel, the ISP division of Grupo Clarín, which publishes the region's most widely read newspaper and owns several major broadcasting and other media properties. Telefónica leads the market in Colombia, in collaboration with government, while in Chile all of Telefónica's operations have been consolidated under the name which formerly identified its mobile division, Movistar. ${ }^{7}$

\section{People of Latin American origin in Australia as a media market}

Whereas the media markets of Latin American countries are huge and thoroughly commercialised, and dominated by major corporate players at global, regional and national levels, people of Latin American origin in Australia constitute a niche market which has inherent commercial limitations, and which relies for its existence on the direct involvement of individuals and their communities, as well as on the indirect support of government. The term 'people of Latin American origin' is the appropriate term to use here, since the media market seeks to include not only the 86,156 Australian residents who declared in the 2006 Census that they were born in South America, Central America or the Caribbean, but the further 93,795 who said they were of such ancestry. This adds up to 179,951 , less than one per cent of the Australian population. Note that the corresponding information for the 2011 Census is not available at time of writing, although it has counted 111,400 people who speak Spanish at home, 22 per cent of whom were born in Australia. ${ }^{8}$ Thus, the first limitation is the size of the market, but the difficulties are more complex than that, in that the market is significantly divided by language, national identity and ideological orientation.

By far the greatest majority of people of Latin American origin in Australia have Spanish as their mother tongue, the significant exception being the Portuguesespeaking population of Brazilian origin, which requires a separate analysis. Just as native-born Australians enjoy the privilege of having a world language as their mother tongue, so do Latin Americans with Spanish, but this common language conceals underlying differences not only between national groups, but within them. It is important to appreciate that, just as Australians or North Americans are not English, even if that is what we call the language we speak, Latin Americans speak Spanish but distinguish themselves not only from Spaniards, but from

7 Ibid.; ‘Redusers, Relevamos los Proveedores de Internet de Argentina'; Telefónica, 'About Telefónica Latinamérica'.

8 Australian Bureau of Statistics, '20680-Country of Birth of Person (minor groups) by Sex-Australia 2006'; '20680-Ancestry (full classification list) by Sex-Australia 2006'; 'Reflecting a Nation: Stories from the 2011 Census, 2012-2013'. 
each others' nationalities. As well, in the same way as English in England differs from its Australian, North American and other variants, just so does Spanish in Spain differ from the 'Spanishes' of Latin America.

This 'pluricentric' character of Spanish ${ }^{9}$ has both advantages and disadvantages from the point of view of media market formation. As minority media, Spanish-language media are able to address a wider range of nationalities than many other minority language media in Australia: Spanish is the official language of 19 countries in Latin America, including those from which most Latin American immigrants have come to Australia-Chile, El Salvador, Argentina and Uruguay. Yet even after more than two decades in which migration from Latin America had totally eclipsed that from Spain, Australia's oldest Spanish-language newspaper, El Español en Australia, dating from 1965, was still giving preference to stories from Spain, as the title implies, rather than catering to those from the new source countries. ${ }^{10}$

To take a related example; unlike speakers of, say, Croatian, Spanish speakers form a large enough audience for SBS to be able to provide a television news service in Spanish every day of the week, just as it does for several other of the larger minority language groups in Australia. However, that service comes from RTVE (Radio Televisión Española), the national broadcaster of Spain, except on Sundays, when news from Chile's state broadcaster, Televisión Nacional de Chile is broadcast as 'Latin American News'. Spanish speakers are thus at an advantage over speakers of most national languages, in that, regardless of their country of origin, they can be aggregated into an audience for news in Spanish, but at a disadvantage in the sense that, unless they are Spanish or Chilean, the news that they get is not from their particular country of origin nor in their own vernacular. Similarly, the much smaller audience of Brazilians is provided with a news service in Portuguese, but it comes from RTP (Rádio e Televisão de Portugal), Portugal's national broadcaster.

Whether for commercial or public service purposes, the traditional media for minorities have the problem of achieving and maintaining critical mass, the level at which readership or audience size becomes commercially viable or can justify public expenditure. ${ }^{11}$ In this regard, the owners of such media have a vested interest in emphasising commonality at the expense of difference, and this encourages the practice of 'aggregation', ${ }^{12}$ that is, minimising the linguistic, national, ideological and other divisions within the target community, or communities, and accentuating what they have in common. Even in the United

9 Michael Clyne and Sandra Kipp, Pluricentric Languages in an Immigrant Context: Spanish, Arabic and Chinese, 1999.

10 María-Teresa Herrera-Keightley, 'The Spanish Language Ethnic Press in Australia', 1989, pp. 93-107.

11 John Sinclair and Stuart Cunningham, 'Diasporas and the Media', 2001, pp. 1-34.

12 Guilherme D. Pires and John Stanton, Ethnic Marketing: Accepting the Challenge of Cultural Diversity, 2005. 
States, where the self-identifying census category of 'Hispanic' or 'Latino' has come to constitute over 16 per cent of that country's total population of 308.7 million, that is, more than 50.5 million Hispanics in over 308 million people, ${ }^{13}$ language is used as a basis of commonality amongst peoples of diverse ethnic or national origins. Spanish-speaking minorities in the US are in a unique position in that they are served by two national television networks as well as abundant local press and radio media. The critical mass of the audiences so formed is great enough to merit the production of both programming and advertising specifically for them. Yet even so, there is an aggregation process at work which emphasises the unity wrought by the speaking of Spanish at the expense of actual diversity, in which people identify themselves as Mexican-American, Cuban-American, or even just American. ${ }^{14}$

From the point of view of commercialising a minority audience, it can be readily understood how the traditional print and broadcasting business model requires the aggregation of a critical mass of people whose attention is attracted by the provision of certain information and entertainment, so that the readership or audience so formed can then be sold to whichever advertisers want to gain access to them. Classically, this has been the basis on which the mainstream commercial press has developed, but minority newspapers, particularly in languages other than English, are restricted in the size and range of advertisers that they are able to attract. Most large mainstream advertisers tend to feel uncertain about the value of targeting minorities. Often there is a perception that minorities, particularly recently arrived immigrants and refugees, have too little purchasing power to be worth the trouble, while with long-established groups, the advertisers' perception is that they will have assimilated and do not require any special targeting. There is also the crucial issue of the lack of measurement: as for other minority newspapers in Australia, there are no audited circulation figures for the Spanish-language press, nor do they have the resources to do readership research, so larger advertisers prefer to use the measured, mainstream media. ${ }^{15}$

Yet this being said, the resistance or perhaps indifference which large advertisers show towards minority marketing should not be exaggerated, since there are certain major corporations that do take it seriously, particularly in the form of what is called 'co-operative advertising'. This is when a large global or national advertiser collaborates in advertising with a retailer of its products or services. An unpublished content analysis of advertising in Australian Spanish-language newspapers yields the examples of ads for Toyota and Ford local car dealerships,

13 US Census Bureau, 'The Hispanic Population of the United States'.

14 Arlene Dávila, Latinos Inc.: The Marketing and Making of a People, 2001.

15 Alvin M. Chan, 'Tapping the multicultural market in Australia', 2006, pp. 238-52; Sophia Russell 'Waking up to Multicultural Marketing', B\&T, 27 April 2007, p. 8. 
alongside local travel agencies promoting LAN (Línea Aérea Nacional), Chile's national airline, and Western Union, the US-based international commercial services corporation. Travel agencies were in fact the most frequently occurring type of advertiser across the four papers in the study, typical of the small scale and community-specific character of most of the other kinds of advertiser, some of them not even commercial: social clubs, sports associations and community broadcasters. Along with migration and other legal services, and specialised food outlets, these are mostly advertisers in and of the community which they seek to reach. ${ }^{16}$

However, to look more generally at marketing to minorities in Australia, the role of government deserves special note. The federal government has fostered minority marketing, both as an advocate and as an advertiser. Past pursuit of multiculturalism and productive diversity policies has required close involvement in 'multicultural marketing' by government, including subsidies in the form of a fixed allocation of its print media budget to the 'ethnic' press. ${ }^{17}$ Apart from both federal and state government departments advertising their services and pursuing particular campaigns from time to time, government-owned entities, such as the health insurance company Medibank Private, are prominent amongst advertisers in the minority media. ${ }^{18}$ An informed contemporary source within the industry estimates that 48 per cent of print advertising is from government.

There is a sense in which government has sought to prime the pump for other large advertisers, in a situation which might otherwise amount to what economists call 'market failure'. Similarly, some state governments have been consistent promoters of minority marketing: New South Wales, the most populous state, still conducts the Australian Multicultural Marketing Awards it implemented in 1991. ${ }^{19}$ Thus, in Australia, government is one of the major forces pushing minority marketing and media, putting itself in the company, and as clients of, such like-minded private sector interests as the Australian multicultural divisions of global marketing communications groups: Etcom, connected via national parent company STW to WPP globally, and the McCann Worldgroup-linked Multicultural Marketing and Management.

The situation with the electronic media is more complex, not only as it concerns the mix of public, private and community involvement, but in regard to transformations underway in the underlying commercial business model itself. While historically this model has functioned well for majority audiences in the

16 Leticia Worley, 'Cultural Diversity in Print Advertisements: Spanish-language Newspapers', Unpublished research paper, Victoria University, Melbourne, 2005.

17 Corrine Condie, Multicultural Marketing, Canberra, Department of Immigration and Multicultural Affairs, 1997.

18 Russell, Sophia, 'Waking Up', 2007, p. 8.

19 Ian F. Wilkinson and Constant Cheng, 'Multicultural Marketing in Australia: Synergy in Diversity', Journal of International Marketing, 7: 3, 1999, pp. 106-25. 
golden age of mass media alluded to earlier, the advent of subscription-based or 'pay- $\mathrm{TV}^{\prime}$ made possible by satellite and cable delivery has given rise to an alternative model in which the media owner can derive revenue merely from providing the service to subscribers, either with no advertising at all, or with advertising in an attenuated form. While such a model still needs a minimum number of subscribers to be viable, it does not necessarily require the physical concentration of those subscribers in the same geographical area, thus transcending the earthbound limitations of free-to-air broadcasting.

In fact, such 'post-broadcasting' distribution technologies as satellite-to-cable and direct-to-home or DBS (direct broadcast satellite) television, now being followed by nascent internet television delivery systems such as IPTV (internet protocol television) made possible by the spread of digital broadband, are particularly well-suited to providing services to widely dispersed subscribers with specialised demands, and minority language speakers are an excellent case in point. For several years now, individuals have been able to mount a satellite dish on the roof and pick up programming from their home country, however isolated they might be. More recently, companies have arisen to provide more user-friendly packages or 'bouquets' of international channels on a subscription basis. This is the phenomenon of 'global narrowcasting': services for self-selecting, widely distributed audiences, of which the diaspora of linguistic and/or ethnic minorities is a prime example.

An extensive mapping study of satellite television flows around the world in the 2000s observes that although national markets continue to be the main target for the bulk of transmissions, an impressive array of international services flows across national borders, and not only in major world languages like Spanish, but minority languages such as Basque. The US case is most extreme: 'In the best of cases nine out of every 10 people in the United States who speak a language other than English at home have the possibility of gaining access to satellite television broadcasts in their family language'.$^{20}$ However, the Australian experience has been that satellite services are not commercially viable, given the small size of most linguistic minority audiences. On the other hand, specialised services are becoming available over the internet, in addition to other kinds of online information and entertainment.

Finally, to understand the media environment in Australia for people of Latin American origin, or indeed of whatever source, the role of the public and community media sectors must be taken into account. As noted at the outset, SBS is a public broadcasting institution which provides national 'ethnic' radio and 'multicultural' television free-to-air broadcasting services, as well as online

20 Josu Amezaga Albizu, 'Geolinguistic Regions and Diasporas in the Age of Satellite Television', International Communication Gazette, 69:3, 2007, pp. 239-61, p. 254. 
access. The two radio networks (AM and FM) are defined as 'ethnic' in that they provide programs in a host of community languages, while the two television channels are 'multicultural' in the sense that most programs are in English, but the wide breadth of non-English entertainment - although not news - programs are subtitled in English. SBS is partly funded from the federal government budget, but also by advertising as on the commercial channels. It has its own board and professional management, at arm's length from both government and the communities it serves. ${ }^{21}$

Augmenting SBS's role, there is also a significant community broadcasting sector which gives non-English-speaking groups direct access to the airwaves. A notable example is 3ZZZ, a radio station which broadcasts on FM throughout Melbourne, but is accessible nationally over the internet. It is mainly funded by listener subscriptions, but does have sponsorship, as distinct from commercial advertising. It is owned and managed by a non-profit community organisation, and run by volunteers who present programs in many languages. ${ }^{22}$ As well, Australian cities have several local community radio stations, some of which have programs mounted by non-English-speaking groups. Regarding television, there are community stations licenced in the major cities which have programs by and for various non-English-speaking community groups. ${ }^{23}$

\section{The media environment for people of Latin American origin in Australia}

At this point, we can now turn to review the whole range of media offerings for Latin Americans in Australia. We should begin with the distinct case of Portuguese-speaking Brazil, given that it is Latin America's largest nation in terms of its economy, its territory and its population. However, people of Brazilian origin form one of the smallest, albeit fastest-growing Latin American communities in Australia. The 2006 Census counted 6,647 residents born in Brazil, with a further 7,491 of that ancestry. ${ }^{24}$ As with Latin Americans in general, the majority, by far in this case, lived in Sydney. Given the absence of critical mass, there are no Brazilian newspapers, but the Brazilian communities in Sydney ${ }^{25}$ and Melbourne ${ }^{26}$ do have websites which feature newsletters as

\footnotetext{
21 Ien Ang, Gay Hawkins and Lamia Dabboussy, The SBS Story, Sydney, University of New South Wales Press, 2008.

22 3ZZZ, Melbourne Ethnic Community Radio.

23 Department of Broadband, Communications and the Digital Economy, 'Community Television'.

24 Australian Bureau of Statistics, '20680-Country of Birth of Person (full classification list) by Sex-Australia

2006'; '20680-Country of Birth of Person (minor groups) by Sex-Australia 2006'.

25 BRACCA,' Brazilian Community Council of Australia'.

26 ABRISA, 'Brazilian Association for Social Development and Integration in Australia'.
} 
well as guides to services and events; community announcements about film screenings, language classes and the like; very modest local classified advertising; and links to Brazilian newspapers and other information sources. A particularly interesting link is to 'Brazilians in the world', which is a site maintained by the Brazilian Ministry of Foreign Affairs for the benefit of the worldwide diaspora of Brazilians. ${ }^{27}$ As for electronic media, SBS provides a radio program in Portuguese, as well as the television news service aired weekly on SBS One and daily on SBS Two.

In spite of the theoretical advantages of the technology, specialised television subscription services, not only for Spanish and Portuguese speakers but most linguistic minorities in Australia, have had a history of failure. Two such services arose during the 2000s, but both had disappeared by 2012. Firstly, in 2004, Sydney-based United Broadcasting International Pty Ltd, trading as UBI World TV, emerged from the ashes of Television and Radio Broadcast Services (TARBS), a similar but unsuccessful prior business. Over digital satellite, it offered Spanish speakers international services from Chile (both Chilevisión and Canal 13), Argentina (Telefé), Colombia (RCN), Mexico (Galavisión) and Spain (TVE), along with special interest Latin film, music and telenovela channels. Portuguese speakers could subscribe to a package of telenovelas on TV Globo from Brazil, in addition to one public and one private channel from Portugal. The other service was SelecTV, owned by Bruce Gordon's WIN Corporation, the major regional media and telecommunications company. It offered a more limited range: TV Chile, the international channel of the national broadcaster, Televisión Nacional de Chile; Latele Novela, a packaged telenovela channel; EuroNews; Fashion TV; and also TVE.

In 2011, SelecTV went into voluntary administration, never having made a profit. They had 45,000 subscribers (across all languages), but argued that they needed 80,000. Within 18 months, UBI collapsed, having 55,000 subscribers at that time, and $\$ 25$ million in debt. ${ }^{28}$ Even when augmented by advertising revenue, it would appear that such pay-TV services lack the critical mass to be commercially viable.

Spanish speakers still have access to televisual news and entertainment on the public and community channels, but on a limited schedule, rather than as a continuously available service. Mention has already been made of SBS's news services from the national broadcasters of Spain and Chile, and the limits of their appeal. SBS also shows films, on an irregular basis, from Spain and Latin

27 Brasileiros no mundo, 'Ministério das Relações Exteriores', Brasil.

28 Media Spy, 'Time called on WIN's pay TV company'; Perthnow, 'Australia's foreign TV service goes belly up'. 
America, but like the news, the selection of films reflects their availability on the international market rather than the composition of the national origins of the potential audience.

In community television, Antena Hispana, a not-for-profit production company with volunteer personnel, has been producing programs for the Channel 31 community television channel in Melbourne since 1996, when its Spanishlanguage program 'Entre Todos' first appeared. From 2004 until 2010, it also produced 'Fusión Latina', in English, which was shown interstate on the community stations TVS in Sydney, QCTV in Brisbane, C31 in Adelaide, and, as of 2010, on WTV in Perth. These programs covered community events and issues, and 'Hispanic culture's food, music, dance and language'. ${ }^{29}$

With regard to radio, there are also public and community programs available. SBS Radio broadcasts one or two hours of programming in Spanish every day, which is also available nationally, whether on AM or FM, digital, online or podcast. The aforementioned 3ZZZ has at least one program in Spanish each day throughout the week, accessible nationally. In Melbourne, one of Australia's first community radio stations, 3CR, has a number of Spanish-language or bilingual programs during the week over AM and online, mainly progressive news and current affairs from Latin America, such as 'Voice of Chile', ${ }^{30}$ while Brisbane's ethnic community station 4EB FM has separate Spanish, Portuguese and Latin American programs each week. ${ }^{31}$ The exception to this predominantly public and community scene is a privately owned, continuous, commercial Spanishlanguage service, Radio Austral. Beginning in 1992 and broadcast out of Sydney, where it is available on FM, and accessible elsewhere over the internet, Radio Austral offers news, current affairs, sport and music, supported by advertising. ${ }^{32}$

Turning now to print, there is only one newspaper published more than once a week, The Spanish Herald, which comes out each Tuesday and Thursday, with a print run of 1,400. It reaches into all states and territories, although most of its circulation is in New South Wales. It is notable that all of the Spanish-language press is based in Sydney, consistent with the distribution of people of Latin American origin, though El Español en Australia, with a print run of 1,200, is more evenly distributed in sales nationally. Others, with less than 1,200, are Extra Informativo and Noticias y Deportes. ${ }^{33}$

Note that most of these circulation figures have not varied much in the last ten years, during which there has been a worldwide downward trend in newspaper

\footnotetext{
29 Antena Hispana.

$303 \mathrm{CR}$, 'About 3CR'.

31 4EB FM, 'About Radio 4EB'.

32 Radio Austral, 'Radio Austral Spanish Radio Network'.

33 Unpublished research by Robert Austin, provided in personal communication from Nelson Cabrera,

Director of El Semanario en Español, 10 April 2013; Worley, 'Cultural Diversity', n.p.
} 
readership that these papers are unlikely to have escaped. The papers survive not so much on circulation as advertising, particularly from government, which is in effect a public subsidy. Furthermore, there is a tendency for newspaper readers to be concentrated amongst the older members of the population. By contrast, as Professor Alfredo Martínez Exposito observes, 'Younger generation Latinos are using the internet like everyone else, that is, in forms which challenge traditional audience modes - peer to peer, blogs, social websites and so on have largely replaced the newspaper and the news bulletin for young people'. ${ }^{34}$

The trend to online communication is apparent with the magazine Viva. From 2000 to 2010, it came out as a print publication every two months, claiming a circulation of 7,000. It is now online as a monthly. Unlike the newspapers, Viva is in English, and oriented very much towards participants in a Sydney-based crossover youth culture, with its coverage of Latin music, dance and nightlife. In effect, it is 'the only Australian lifestyle magazine about the Latin world' ${ }^{35}$ Similar magazines that were available in print format only, notably Coqueta and Latin Time, are now defunct.

Indeed, the internet is by far the most vibrant medium in the Spanish-language mediascape in Australia, with both not-for-profit and commercial dimensions, but it is subject to instability. The website of the Melbourne-based Chilean community organisation, Fonda la Clínica, formerly provided a good example of grass-roots use of the internet, with extensive community news and useful links in Spanish, but, at the time of writing, had not been updated since September 2012. ${ }^{36}$ Another non-commercial site, that once allowed Spanish speakers to watch or download video podcasts on current affairs, politics, medicine, education and the like, now has its domain name up for sale. ${ }^{37}$ On the other hand, enterprising individuals have initiated online news and information sites. A Sydney-based journalist from Uruguay provides a professional internet news service in Spanish, plus quality features and a community directory, claiming a notional but highly unlikely estimated universe of 90,000 Latin American families in Australia. Again, a Catalan journalist in Melbourne maintains Spanish Australia, more of a cultural and lifestyle site, of interest to a hip Spanish, Latin American and English-speaking audience. ${ }^{38}$ However, the continuity of these sites depends absolutely on what the individuals sustaining them do with their lives: for example, El Diario Australiano, a serious news and feature article service in Spanish, ceased when the Venezuelan journalist running it moved overseas.

34 Alfredo Martínez Exposito, Professor of Spanish, University of Melbourne, Personal email communication,

5 March 2010.

35 Viva, 'Viva Magazine'.

36 Fonda la Clinica.

37 Huge Domains.

38 Latinhub. 
Much less transitory has been an online newspaper, El Semanario en Español. Established in 2007 and now received by 5,200 subscribers, nationally and internationally, this electronic weekly has achieved a circulation which compares more than favourably with the printed press, as detailed earlier. ${ }^{39} \mathrm{~A}$ rather different kind of internet venture is Latino America Viva. This describes itself, inaccurately, as 'the only Latin daily online news in Australia'. In fact, it is more of a content aggregation site, run by a marketing consulting company, offering magazine-style content with links to local and Latin American news sites, and carrying display and classified advertising, as well as sponsorships. ${ }^{40}$

To conclude, we have seen that, whereas the mainstream both in Australia and in the major countries of Latin America is dominated by large private media corporations, Australia is distinct because of the role assigned to public broadcasting in particular. The public broadcasting institution SBS is prominent in the provision of services for people of Latin American and other non-English-speaking immigrant origin in Australia, while government more generally gives strong support to the community's own media via its high level of advertising. Looking beyond this subvention by government, community television and radio and even some online services are well-named, both in the sense that they rely on the good will and voluntarism of individuals in the community, and that they are capable of reflecting the ethno-national composition of the Spanish-speaking community in a way that public broadcasting does not. The commercial side of Spanish-language media in Australia is largely restricted to the press. While the titles are well established, the organisational basis is more small-scale entrepreneurial than corporate, and the advertising revenue is to a large degree limited: reliant on government, a finite revenue source.

All this being the case, and given the inherent limitations which have been discussed, it is hard to see much scope in the immediate future for further development of the Spanish-language media market in Australia. The dependence of the press on government advertising, the demise of the specialised television subscription services, and the marginal and fugitive nature of other media offerings outside SBS all make clear the commercial limitations of a small market, particularly for traditional print and broadcast media. On the other hand, the discernible shift to the provision of news and entertainment services over the internet, along with the emergent technology of online television, points the way to a future mediascape in which local, grass-roots ventures can co-exist with access to more transnational fare.

39 Nelson Cabrera, Director of El Semanario en Español, Personal communication by email, 10 April 2013.

40 Latino America Viva. 


\section{References}

3CR, 'About 3CR', http://www.3cr.org.au/about_3CR, accessed 4 April 2013.

3ZZZ, Melbourne Ethnic Community Radio, http://www.3zzz.com.au/, accessed 4 April 2013.

4EB FM, 'About Radio 4EB', http://www.4eb.org.au/?q=node/6, accessed 5 April 2013.

ABRISA, 'Brazilian Association for Social Development and Integration in Australia', http://www.abrisa.org.au/en/index.htm, accessed 4 April 2013.

Albizu, Josu Amezaga, 'Geolinguistic Regions and Diasporas in the Age of Satellite Television', International Communication Gazette, 69: 3, 2007, pp. 239-61.

Ang, Ien, Gay Hawkins and Lamia Dabboussy, The SBS Story, Sydney, University of New South Wales Press, 2008.

Antena Hispana, http://latinoamericainaustralia.blogspot.com.au/2013/03/ antena-hispana-fiesta.html, accessed 4 April 2013.

Austin, Robert, (unpublished research) provided in personal communication from Nelson Cabrera, Director of El Semanario en Español, 10 April 2013.

Australian Bureau of Statistics, '20680-Country of Birth of Person (full classification list) by Sex-Australia 2006', http://www.censusdata.abs.gov. au, accessed 12 April 2013.

'20680-Country of Birth of Person (minor groups) by Sex-Australia 2006', http://www.censusdata.abs.gov.au, accessed 12 April 2013.

. 'Reflecting a Nation: Stories from the 2011 Census, 2012-2013', http://www.abs.gov.au/ausstats/abs@.nsf/Lookup/2071.0main+featur es902012-2013, accessed 26 April, 2013.

BRACCA, 'Brazilian Community Council of Australia', http://bracca.org/2012/, accessed 4 April 2013.

Brasileiros no mundo, 'Ministério das Relações Exteriores', Brasil, http://www. brasileirosnomundo.itamaraty.gov.br/, accessed 4 April 2013.

Business News Americas, 'Folha merges with UOL to form Folha-UOL', http:// www.bnamericas.com/news/telecommunications/Folha_merges_with_UOL_ to_form_Folha-UOL, accessed 27 March 2013. 
Cabrera, Nelson, Director of El Semanario en Español, Personal communication by email, 10 April 2013.

Chan, Alvin M. 'Tapping the multicultural market in Australia', in C. P. Rao (ed.), Marketing and Multicultural Diversity, Aldershot, Ashgate, 2006, pp. 238-52.

Clyne, Michael and Sandra Kipp, Pluricentric Languages in an Immigrant Context: Spanish, Arabic and Chinese, Berlin and New York: Mouton de Gruyter, 1999.

Condie, Corrine, Multicultural Marketing, Canberra, Department of Immigration and Multicultural Affairs, 1997.

Dávila, Arlene, Latinos Inc.: The Marketing and Making of a People, Berkeley, University of California Press, 2001.

Department of Broadband, Communications and the Digital Economy, 'Community Television', http://www.dbcde.gov.au/television/community_ television, accessed 4 April 2013.

Exposito, Alfredo Martínez, Professor of Spanish, University of Melbourne, Personal email communication, 5 March 2010.

Fonda la Clínica, http://www.fondalaclinica.com.au/, accessed 9 April 2013.

Herrera-Keightley, María-Teresa, 'The Spanish Language Ethnic Press in Australia', in Abe W. Ata and Colin Ryan (eds), The Ethnic Press in Australia, Melbourne, Academia Press and Footprint Publications, 1989, pp. 93-107.

Huge Domains, http://www.holahispanos.com/, accessed 9 April 2013.

Internet World Stats, 'Latin American Internet Usage Statistics 2011', http:// www.internetworldstats.com/stats10.htm, accessed 27 March 2013.

Latinhub, http://www.latinhub.com.au/; Spanish Australia, http://www. spanishaustralia.org, accessed 9 April 2013.

Latino America Viva, http://www.latinoamericaviva.com.au/, accessed 9 April 2013.

McKnight, David, Rupert Murdoch: An Investigation of Political Power, Crow's Nest NSW, Allen \& Unwin, 2012.

Media Spy, 'Time called on WIN's pay TV company', http://www.mediaspy. org/2011/02/04/time-called-on-wins-pay-tv-company/, accessed 13 October 2013.

News Corporation, 'DIRECTV Group and News Corporation Announce Reorganization and Consolidation of Satellite TV Platforms in Latin America', 2004, http://www.newscorp.com/news/news_221.html, accessed 27 March 2013. 
Paul BuddeCommunications Pty Ltd, 'Latin American Broadbandand Internet Market', http://www.marketresearch.com/product/display.asp? productid=2392719, 21 July 2009, accessed 29 March 2013.

Perthnow, 'Australia's foreign TV service goes belly up', http://www.perthnow. com.au/business/australias-foreign-tv-service-goes-belly-up/storye6frg2rc-1226405967387, accessed 5 April 2013.

Pires, Guilherme D. and John Stanton, Ethnic Marketing: Accepting the Challenge of Cultural Diversity, London: Thomson, 2005.

Radio Austral, 'Radio Austral Spanish Radio Network', http://radioaustral.com. au/about/, accessed 5 April 2013.

'Redusers, Relevamos los Proveedores de Internet de Argentina', http://www. redusers.com/noticias/relevamiento-de-los-proveedores-de-internet-enargentina/, accessed 4 April 2013.

Russell, Sophia, 'Waking up to Multicultural Marketing', B\&T, 27 April 2007, p. 8.

Sinclair, John and Stuart Cunningham, 'Diasporas and the Media', in Cunningham, Stuart, and John Sinclair (eds), Floating lives: The Media and Asian Diasporas, Lanham, Rowman \& Littlefield, 2001, pp. 1-34.

Sinclair, John, Latin American Television: A Global View, Oxford and New York: Oxford University Press, 1999;

Sobre UOL, 'UOL, the best internet content', http://sobreuol.noticias.uol.com. br/index_en.jhtm, accessed 27 March 2013.

Tabakoff, Nick, 'Historic shift for News as it returns to publishing roots', The Australian, 5 December 2012, p. 19.

Telefónica, 'About Telefónica Latinamérica', http://www.telefonica.com/ en/latam/html/ about_telefonica_latin_america/home.shtmla, accessed 4 April, 2013.

US Census Bureau, 'The Hispanic Population of the United States', http://www. census.gov/population/hispanic/data/2011.html, accessed 4 April 2013.

Viva, 'Viva Magazine', http://www.vivamagazine.com.au/joomlasite, accessed 9 April 2013.

Wilkinson, Ian F. and Constant Cheng, 'Multicultural Marketing in Australia: Synergy in Diversity', Journal of International Marketing, 7: 3, 1999, pp. 106-25.

Worley, Leticia, 'Cultural Diversity in Print Advertisements: Spanish-language Newspapers', Unpublished research paper, Victoria University, Melbourne, 2005. 
This text taken from Australia and Latin America: Challenges and Opportunities in the New Millennium, Edited by Barry Carr \& John Minns, published 2014 by ANU Press, The Australian National University, Canberra, Australia. 